\title{
Architectural Engineering Approach to Developing a Matrix for Planning in Extreme Environments
}

\author{
Olga Bannova ${ }^{1}$ and Maria Nystrom ${ }^{2}$ \\ ${ }^{1}$ School of Architecture, Chalmers University of Technology, Sweden and University \\ of Houston., 122 College of Architecture bldg.., University of Houston, Houston TX \\ 77204, USA, obannova@central.uh.edu \\ 2 School of Design and Crafts HDK, University of Gothenburg, Box 131, SE 40530 \\ Göteborg and School of Architecture, Chalmers University of Technology, SE 41296 \\ Göteborg, Sweden, maria.nystrom@chalmers.se
}

\begin{abstract}
Extreme environments on Earth share similar facilities and operations, design and planning challenges. Each environment presents special lessons regarding housing design, crew/staff operations and training, and equipment and logistical requirements for human activities. The paper discusses these challenges and lessons. Recurrent and specific to environment and conditions events are outlined and categorized based on case studies reviews and literature summary. Understanding of relationships and influences between different facets of human society and architecture can help to find a design approach which would optimize needs and requirements for various types of people living in different environments, societies and cultures. Environmental conditions affecting architectural requirements include form developing factors, site orientation and circulation, and budget considerations. They have to be addressed at the programming design stage in order to avoid costly adjustments at later development stages. It is even more critical in case of designing for challenging environments.
\end{abstract}

\section{INTRODUCTION}

There are certain similarities between cold and hot deserts, permafrost and other polar regions: extreme temperatures, foundation problems, high standards for insulation materials, resources limitations (including people); but they differ depending on local cultural and social traditions and climate challenges specific to particular region. Environmental hardships create structural and infrastructural challenges and can be reflected in sets of architectural requirements.

Today life conditions and environment itself are changing rapidly and it becomes essential to respond to that in design and planning just as fast. It is also critical for successful practice in extreme environments and disaster areas to be able to proceed with construction almost immediately after the disaster happened or a decision to start exploration or other development is made and personnel and crew has to be moved to a remote location within limited timeframe. 
Special attention should be given to environmental characteristics that influence architectural and planning requirements and program prerequisites definition. There are patterns in architectural requirements sets for different extreme locations that have to be analyzed prior to design decisions are made. Comparisons between infrastructure elements conditions in different extreme environmental settings demonstrate that they share similar characteristics and can be addressed by following related procedures. For example, any extreme environment poses some limitations and/or hardships for people surviving and maintaining relative physical and psychological comfort. The limitations are usually in:

- $\quad$ Resources;

- $\quad$ Availability of services and/ spaces;

- Mobility and transportation.

These limitations lead to hardships that may include all or some of the following:

- $\quad$ Strong restrictions to execute everyday work tasks;

- Impossibility to perform social interactions or maintain necessary level of privacy;

- Impossibility to fulfill necessary living needs.

This paper introduces an interdisciplinary, comprehensive approach that includes highlighting influences upon general habitat requirements, and constraints upon delivery, construction, and special provisions for safety and hazard intervention. Optimization of such design requirements based on the summary of design aspects is a key element of the proposed programming and planning matrix.

\section{PLANNING CONSIDERATIONS}

This paper outlines prerequisites and reasoning for developing a systematic methodology for planning and design efforts in extreme environments. Although existing methods applied to planning and design in remote and extreme locations address some environment-specific challenges they usually do not cover or include a systematic approach to the design process from preliminary design phase to construction stage and are usually conducted on case-by-case basis (Nielsen, 1999). Sometimes some of previous experiences are used in new conditions but without comprehensive arrangements and systematic methodology it may be misleading and resulting in misusing and waste of resources and time delays.

Despite the fact that there are federal laws, standards and regulations generated by companies, local authorities, developers and other entrepreneurships, they are disconnected at many levels and usually have different objectives which consequently lead to unbalanced design and planning resulting in failure in one or several areas of development (Bell, 2014). This is also critical for creating sustainable environmental and social systems (Rasmussen, 1999). Social systems in extreme environments much more vulnerable and sensitive to changing conditions in any of their subsystems, such as cultural, political, ecological, technological, societal 
(Rasmussen, 1999). Malfunction in one of those subsystems may very easy make the whole system dysfunctional and handicapped (Nuttall, 2005).

Design is one of most complex processes and requires well researched interdisciplinary preparation work including not-traditionally design-related disciplines such as climatology, meteorology, petroleum engineering, etc. Miscommunications or even absence of communication between diverse professions involved in developments in extreme environment of Polar Regions leads to critical mistakes and may result in vast environmental, time and money losses (Rasmussen, 1999).

Efforts in fixing not properly addressed problems later in development process are very costly, time consuming and sometimes too late to be corrected (Reason, 2000). Creating a logical path for planning and maintaining activities in extreme conditions seems to be a vital necessity in pursuit of sustainability in Arctic. The study presented in this report is based on identifying aspects or elements of the proposed model as well as understanding why they are connected. This is important for building a dialogue model for local communities, engineers, individuals, that will serve as a design and development planning tool.

Identification of common priorities, issues and challenges leads to a possibility of creating a common methodology that can be applied to design and planning for various extreme environments and adjusted to diverse harsh conditions. Human requirements and environmental factors specific to each different type of environment, operation and facility must be correlated with resulting planning needs. Some general considerations are listed below in the Table 1:

Table 1. Planning considerations.

\begin{tabular}{|l|l|}
\hline Human requirements & Environmental influences \\
\hline Number of occupants & $\begin{array}{l}\text { Structure selection and construction } \\
\text { options }\end{array}$ \\
\hline Social/cultural influences & Climate/thermal characteristics of the site \\
\hline Time frame/mission duration & Logistical requirements and scheduling \\
\hline Special safety hazards & Types and levels of danger \\
\hline Emergency escape means & Proximity to major transportation modes \\
\hline Recycling of expendables & Type of surface transportation \\
\hline Primary mission objectives/purposes & In-situ resource utilization possibilities \\
\hline
\end{tabular}

\section{METHODOLOGY}

The paper describes several research methods that can be used as foundation for development of proposed methodology. These methods include: 
- Scientific and design methods (data collection);

- Standardized case study approach (case studies analysis);

- Development of Figures Of Merit (based on NASA's approach to data analysis and systematization);

- Analyzing effectiveness and verification of proposed method by means of Living Lab project at Chalmers University of Technology (using it as an evaluating tool).

An ultimate goal of any design process depends on successful identification of a design research problem which always lays in finding a proper "translation from individual, organizational and social needs to physical artifacts" (Hillier \& Leaman, 1976). Architectural approach also includes understanding of consequences of inadequate behavior or actions that caused by inappropriate attitude to the project development and may lead to non-desirable or even catastrophic events. Such understanding should be part of design and planning prerequisites and programming (Reason, 2000).

The multi-dimensional character of the process affects overall design methodology in a way where all components are influenced and influencing one another (Figure 1). Figure 1 summarizes the idea in a multi-dimensional diagram where straight horizontal and vertical connections represent direct dependences and influences while indirect connectors represent conditional but permanent relationships between elements. The integration model or tool's role is to facilitate these relationships and promptly respond to their demands.

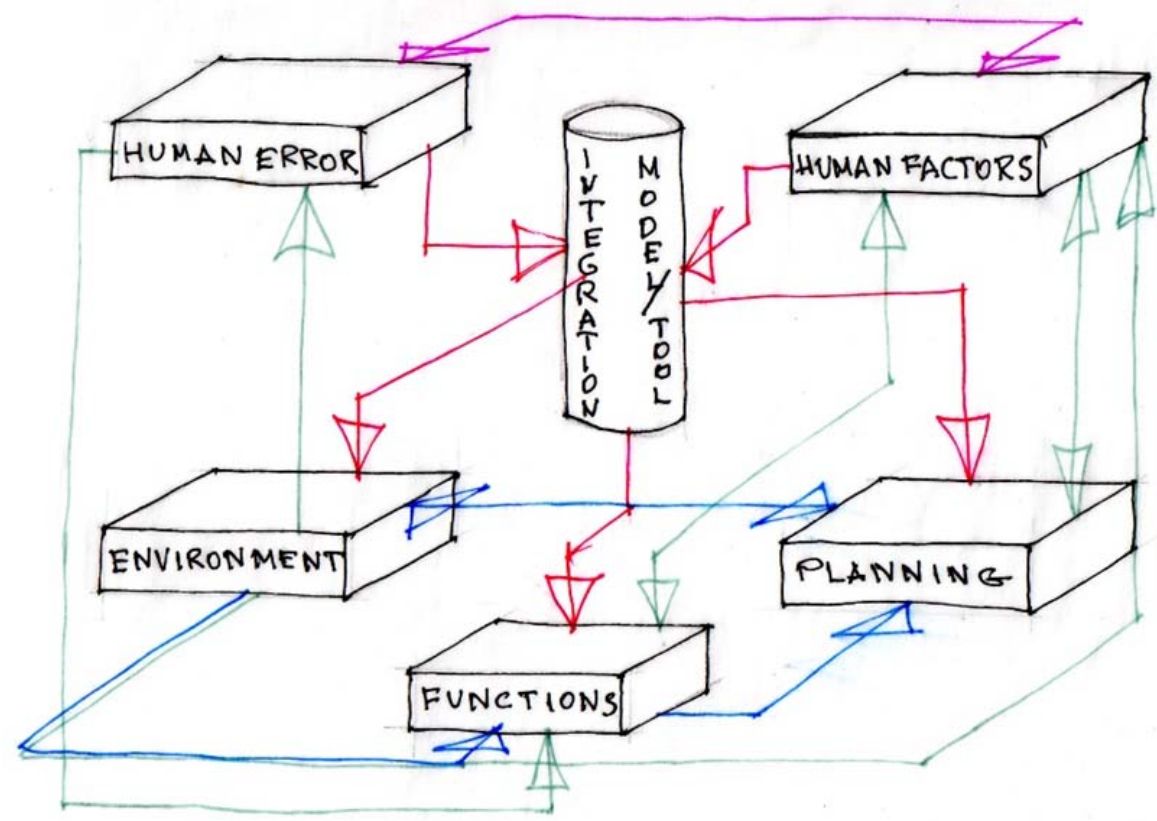

Figure 1. Multi-dimensional model applied to project development process. $O$. Bannova.

Data collection. For better understanding of the current situation with energy companies' exploration plans in polar climates several ConocoPhillips development 
professionals answered a short survey about their work in extreme environments. Three ConocoPhillips managers were interviewed after they answered the survey to expand and summarize the knowledge. The locations of discussed projects include: off-shore platforms, Alaska North Slope developments, Gulf of Mexico (deep-water), Russian Arctic region, and Northern Alberta County in Canada (Table 2). The schedule was the main driver for all these projects as well as cost and safety for operational projects. All of them were challenged with similar problems: remoteness, communication issues between involved parties including contractors, local authorities and workforce and the project management, and logistics problems at different degrees.

Table 2. Projects referred in survey responses.

\begin{tabular}{|l|l|l|l|l|l|}
\hline Lharacteristics & $\begin{array}{l}\text { Off- } \\
\text { shore } \\
\text { rigs }\end{array}$ & $\begin{array}{l}\text { Alaska, } \\
\text { North } \\
\text { slope }\end{array}$ & $\begin{array}{l}\text { Arctic } \\
\text { Russia }\end{array}$ & $\begin{array}{l}\text { Northern } \\
\text { Alberta, } \\
\text { Canada }\end{array}$ & $\begin{array}{l}\text { Gulf of } \\
\text { Mexico }\end{array}$ \\
\hline $\begin{array}{l}\text { Environment/ } \\
\text { climate }\end{array}$ & $\begin{array}{l}\text { Deep } \\
\text { water }\end{array}$ & $\begin{array}{l}\text { Polar, cold } \\
\text { and dry }\end{array}$ & $\begin{array}{l}\text { Polar, cold } \\
\text { and dry }\end{array}$ & $\begin{array}{l}\text { Permafrost, } \\
\text { cold and dry }\end{array}$ & $\begin{array}{l}\text { Deep } \\
\text { water }\end{array}$ \\
\hline Development stage & Finished & Finished & In transition & In progress & Finished \\
\hline $\begin{array}{l}\text { Within schedule and } \\
\text { budget }\end{array}$ & Yes & Yes & $\begin{array}{l}\text { Schedule - } \\
\text { yes, } \\
\text { Budget - no }\end{array}$ & N/a & Yes \\
\hline
\end{tabular}

Although all mentioned projects were referred as successful, the corporate criteria for "success" or "failure" is only based on safety and execution within a given timeframe and budget (ConocoPhillips, 2006). It was revealed during follow-up interviews that many of other elements of planning and execution processes are either dismissed or not given a proper attention and that may sometimes jeopardize the project flow.

The survey contributors pointed out independently that effective and timely communications between all participants and at all stages of the process is a foundation of success regardless of major drivers and criteria of the success applied in the project. Most important drivers of success in all projects are safety, cost, schedule and quality while last three may not be necessarily placed in that order. Other impacting aspects of success or failure include:

- Professional level of personnel;

- Number of qualified personnel on site and in decision making;

- Available infrastructure;

- Available resources.

Case studies. Table 3 summarizes environmental and geographical characteristics of two projects used as case studies for development of proposed methodology. Case study I (Polar desert) is located above polar circle on the top of tree kilometers of Greenlandic glacier and in the center of Greenland. The subject of the Case study II (Boreal) is in wetlands of Amur River of Russian eastern Siberia. Both geographical 
locations present challenging for life conditions and demand proper response from architects and planners when planning development activities in the regions.

Table 3. Characteristics of investigated case studies.

\begin{tabular}{|c|c|c|c|c|}
\hline zone /climate & temperature & weather & geography & case study \\
\hline Case I, Polar desert & $\begin{array}{l}\text { Mean } \\
\text { temperature } \\
\text { during warmest } \\
\text { month less than } \\
\text { 10C }\end{array}$ & $\begin{array}{l}\text { Brief summer, } \\
\text { annual } \\
\text { precipitation } \\
\text { less than } \\
250 \mathrm{~mm}\end{array}$ & Greenland & $\begin{array}{l}\text { Summit } \\
\text { science } \\
\text { station }\end{array}$ \\
\hline Case II, Boreal & $\begin{array}{l}\text { Most extreme } \\
\text { temperature } \\
\text { variations, at } \\
\text { least one month } \\
\text { must have a 24- } \\
\text { hour average } \mathrm{t}^{\mathrm{O}} \\
\text { of 10C }\end{array}$ & $\begin{array}{l}\text { Subarctic, } \\
\text { short and } \\
\text { warm } \\
\text { summer, cold } \\
\text { winter }\end{array}$ & $\begin{array}{l}\text { Russian } \\
\text { southeastern } \\
\text { Siberia } \\
\text { (Amur } \\
\text { region) }\end{array}$ & $\begin{array}{l}\text { Muraviovka } \\
\text { park for } \\
\text { sustainable } \\
\text { land use }\end{array}$ \\
\hline
\end{tabular}

Figures Of Merit (FOM). Using the FOM method helps to identify important lessons that can be applied across different settings which present common priorities, issues and challenges. Such environments include future bases on the Moon and Mars, offshore surface and submersible facilities, polar research and oil/natural gas exploration stations, military desert operations, and natural and man-made emergency shelters.

Even though it may seem not be very practical to compare proposed case studies elements using FOM technique as many of these projects' attributes are rather qualitative than quantitative by the nature of architectural discipline itself, it appears to be important to understand the FOM approach when different design solutions are compared and evaluated. Application of this method to results of case studies research precedes testing and evaluation stage of proposed extreme environment methodology matrix.

Analyzing effectiveness and verification of proposed method. To test and evaluate responsible planning and design practices is proposed to use The 'HSB Sustainable Living Lab', which is a collaborative effort between the largest Swedish co-operative housing association, HSB, and Johanneberg Science Park, and to be built in 2014 as a student housing, located on Chalmers main campus ${ }^{1}$. Its location offers a unique opportunity to merge research, education and outreach.

The goal of the HabLab initiative is to explore new building and construction ideas and concepts, new materials implementation, to test design and planning approaches, develop new technologies and adapt products and systems innovations to

\footnotetext{
${ }^{1}$ http://suslab.eu/partners/chalmers-th/hsb-living-lab/
} 
local context culturally, economically and socially (Nystrom, et al. 2000). An architectural input is focused on a definition of sustainable living environment and design practice exploring students' interactions in design/build process, construction and use of housing units while efficiently optimizing consumption of energy and other resources.

\section{CONCLUSIONS}

Conclusions are drawn upon findings after analyzing and synthesizing the collected data and summary of the most influential and dependable aspects of planning and development activities in extreme conditions.

Analysis of two discussed case studies demonstrated shared and recurrent design aspects that can be addressed in design process in a similar way, which perhaps can help to optimize planning processes for extreme environments conditions starting from first stages of their development. The table 4 below summarizes structural and infrastructural recurrent and specific to case design aspects.

\section{Table 4. Recurrent and unique design aspects.}

\begin{tabular}{|c|c|c|c|}
\hline & & Recurrent & Unique \\
\hline \multirow[t]{2}{*}{$\begin{array}{l}\text { CASE } \\
\text { I } \\
\text { Polar } \\
\text { desert }\end{array}$} & Structure & $\begin{array}{l}\text { Avoid heavy construction } \\
\text { needs; } \\
\text { Interior zoning; } \\
\text { Use of renewable energy; } \\
\text { Use of recycling systems; } \\
\text { Apply tight building envelop; } \\
\text { Optimize elements packaging } \\
\text { for efficient transportation. }\end{array}$ & $\begin{array}{l}\text { Strict limitations applied to } \\
\text { mass and dimensions of } \\
\text { structural elements; } \\
\text { Structurally balance weight } \\
\text { distribution; } \\
\text { Incorporate automatic and } \\
\text { robotic systems. }\end{array}$ \\
\hline & Infrastructure & $\begin{array}{l}\text { Plan for tight transportation } \\
\text { windows; } \\
\text { Develop site zoning; } \\
\text { Minimize } \\
\text { impact. }\end{array}$ & $\begin{array}{l}\text { Year-around assembly } \\
\text { operations are possible; } \\
\text { Very limited transportation } \\
\text { means are available. }\end{array}$ \\
\hline \multirow[t]{2}{*}{$\begin{array}{l}\text { CASE } \\
\text { II } \\
\text { Boreal }\end{array}$} & Stru & $\begin{array}{l}\text { Avoid heavy construction } \\
\text { needs; } \\
\text { Propose interior zoning; } \\
\text { Use of renewable energy; } \\
\text { Use of recycling systems; } \\
\text { Apply tight building envelop. }\end{array}$ & $\begin{array}{l}\text { Constrained construction and } \\
\text { assembly time; } \\
\text { Many transportation means are } \\
\text { available but limited for } \\
\text { economic reasons. }\end{array}$ \\
\hline & Infrastructure & $\begin{array}{l}\text { Plan for transportation limited } \\
\text { by weather conditions; } \\
\text { Develop site zoning; } \\
\text { Minimize environmental } \\
\text { impact. }\end{array}$ & $\begin{array}{l}\text { Many transportation means are } \\
\text { available but limited for } \\
\text { economic reasons. } \\
\text { Create economic and social } \\
\text { sustainability }\end{array}$ \\
\hline
\end{tabular}

Other recurrent design influencing aspects are associated with human factors. They can be combined under non-structural or human-related category where psychological, societal, cultural and mental challenges demonstrate comparable levels of stress and other risk factors. Some of them are summarized in the table 5 below. 
Table 5. Other recurrent and specific aspects influencing design.

\begin{tabular}{|l|l|l|l|}
\hline \multicolumn{2}{|l|}{} & Recurrent & Unique \\
\hline $\begin{array}{l}\text { CASE } \\
\text { Polar } \\
\text { desert }\end{array}$ & Individual & $\begin{array}{l}\text { Psychological: motivation for } \\
\text { excellence in performance; } \\
\text { acceptance of some hardships } \\
\text { and challenges. Physical: regular } \\
\text { exercising, demand for personal } \\
\text { spaces. }\end{array}$ & $\begin{array}{l}\text { Total isolation during } \\
\text { winter-over operations }\end{array}$ \\
\cline { 2 - 5 } & Group & $\begin{array}{l}\text { Social and cultural tolerance; } \\
\text { educational outreach programs } \\
\text { for local communities and } \\
\text { visitors; staff seasonal rotations. }\end{array}$ & $\begin{array}{l}\text { Lack of social or other } \\
\text { group activities other than } \\
\text { scientific researchers } \\
\text { visiting. }\end{array}$ \\
\hline $\begin{array}{l}\text { II } \\
\text { Boreal }\end{array}$ & Individual & $\begin{array}{l}\text { Psychological: motivation for } \\
\text { excellence in performance; } \\
\text { acceptance of some hardships } \\
\text { and challenges. Physical: regular } \\
\text { exercising, demand for personal } \\
\text { spaces. }\end{array}$ & $\begin{array}{l}\text { Constrained construction } \\
\text { and assembly time; Many } \\
\text { transportation means are } \\
\text { available but limited due } \\
\text { to economic reasons. }\end{array}$ \\
\cline { 2 - 6 } & $\begin{array}{l}\text { Social and cultural tolerance; } \\
\text { educational outreach programs } \\
\text { for local communities and } \\
\text { visitors; staff seasonal rotations. }\end{array}$ & $\begin{array}{l}\text { Involvement of local } \\
\text { communities in some } \\
\text { activities and being } \\
\text { involved in local events. }\end{array}$ \\
\hline
\end{tabular}

Optimization of design requirements based on the summary of design aspects presented in Tables 3 and 4 is the next step of the research development. The set of requirements is a key element of the proposed programming and planning matrix.

In a summary, an interdisciplinary, comprehensive approach includes highlighting influences upon general habitat requirements, constraints upon delivery and construction, and special provisions for safety and hazard interventions. Recurrent and diverse design influences include:

- influences driven by transport to remote sites;

- environmental influences upon facilities and construction;

- influences of crew sizes, types of activities and occupancy durations;

- influences of construction methods and support infrastructures;

- $\quad$ special safety and emergency response requirements (Bannova, 2010).

Reflecting dialogues with energy industry professional, researchers, logistics and support crews operating in extreme environments of polar and other remote locations, it is assumed that the most critical influences upon operating and living conditions are related to safety, communication and transportation availability. These influences can be addressed in the proposed methodology. 


\section{REFERENCES}

Bannova, O. (2010). "Terrestrial Analog Selection Considerations for Planetary Surface Facility Planning and Operations.” In: Benaroya H., ed. Lunar Settlements, CRC Press, 375-385.

Bell, J. (2014). Interlinking Engineering and Social Performance into Sustainability using the Triple Bottom Line Principal, Denver, Colorado, Unconventional Resources Technology Conference. (2014).

ConocoPhillips Report (2006). Arctic Energy: for today and tomorrow, Anchorage, Alaska, ConocoPhillips.

Cross, N. (1993). Science and design methodology: a review. Research in Engineering Design, 5(2), 63-69.

Hillier, B., and Leaman, A., (1976). “Architecture as a discipline.” Architectural Research, 5(1), 28-32.

Nielsen, J. B. (1999). A study of environmental conflicts and societal consequences of oil activities in the Arctic. In: Petersen H., and Poppel B., eds. Dependency, autonomy, sustainability in the Arctic, Brookfield: Ashgate Publishing Company, 315-319.

Nuttall, M. (2005). Encyclopedia of the Arctic, Volume 3. New York: Routledge, 1966-1967, 1972-1974.

Nystrom, M. et al. (2010). "East African Academy - a Feasibility Study." Chalmers University of Technology.

Rasmussen, R. O. (1999). "Conditions for sustainable development in the Arctic a general perspective.” In: Petersen H., and Poppel B., eds. Dependency, autonomy, sustainability in the Arctic. Brookfield: Ashgate Publishing Company, 217-228.

Reason, J. (2000). "Human error: models and management.” The Western Journal of Medicine, 172(6), 393. 